\title{
Getting Rid of Strategizing Hindrances - Identifying and Confirming Management Consultant Liabilities
}

\author{
Karen Stander \\ PhD candidate - University of Pretoria \\ E-mail: standk@unisa.ac.za \\ Marius Pretorius \\ University of Pretoria \\ E-mail: Marius.pretorius@up.ac.za
}

\section{Doi:10.5901/mjss.2014.v5n8p102}

\begin{abstract}
In 2009, the management consulting industry reported a 9\% decline in their financial performance. The applied empirical research, which informed this article, was undertaken in an effort to provide an alternative explanation (over and above the $2.2 \%$ decline in the global market economy reported for 2009 by the World Bank) for the observed slump in the financial performance of management consulting firms. The results of the study showed that liabilities (hindrances) that limit the ability of management consultants to strategies successfully are one of the major contributors to the decline in the financial performance of consulting firms. The qualitative research, on which this paper is based, was undertaken from a strategy-as-practice perspective and was conducted in two separate but interrelated phases. First, an extensive literature review aimed at identifying the liabilities discussed in academic works was done. Second, the practical relevance of the identified liabilities was determined by conducting semi-structured interviews. The paper concludes by combing the findings of the study into a conceptual framework, which assists consultants to identify, understand and mitigate the liabilities they are most likely to encounter while assisting organizations in strategizing.
\end{abstract}

Keywords: liabilities; hindrances; management consultants; strategy-as-practice;

\section{Introduction}

A consulting project is deemed successful when a management consultant is able to add value to, and increase the profitability of the organization [definition based on interview responses].

The combined turnover of the top 20 international management consulting firms has been estimated as 297 billion US\$ for 2009 (Kelloggforum, 2010; Vault, 2011). Although substantial, the Deloitte Market Share Analysis Report (Von Uechtritz, 2010) shows a 9\% decline in the management consulting industry and indicates that only six of the top 10 management consulting firms were able to grow their earnings above the industry average of $-9 \%$. The struggle of top firms and the industry's negative growth rate suggest that consultants are encountering hindrances that limit their ability to earn economic rents.

Von Uechtritz (2010) suggests that the industry's inability to earn economic rents is the result of management consultants' (hereafter referred to as consultants) inability to strategize successfully. This inability of consultants to successfully strategize internally has spilled over to their clients, with Neilson, Martin and Powers (2008) reporting that only $40 \%$ of organizations are able to efficiently and effectively implement a corporate or operational strategy.

The inability of consultants to strategize successfully, implied in the Deloitte report, necessitated the researchers to investigate what is hindering the successful completion of a strategy-consulting project. As these hindrances, affect not only consulting firms' ability to earn superior economic rents and sustain competitive advantage, but also that of their clients.

Various authors (Pretorius and Holtzhauzen, 2008; Ooghe and De Prijcker, 2008) agree that an organization is experiencing a liability when it experiences barriers, disadvantages, hindrances, weaknesses, difficulties, accountabilities and responsibilities (liability preconditions) which limit its ability to strategize successfully, gain competitive advantage and earn superior economic rents. A management consultant's apparent "inability" to strategize, resulting from liabilities 
(hindrances), meets the litmus test for a strategic liability. Arend (2004) suggests that exposure to strategic liabilities, such as the "inability" described above, during any stage of a firm's life cycle can result in potential failure of an organization.

The research that informed this article was conducted in two separate but interlinked phases and attempted to answer four questions from a strategy-as-practice perspective to contribute to both Domain $\mathrm{G}$ and Domain $\mathrm{H}$ of the strategy-as-practice typology. The four research questions were:

RQ1: What are the liabilities consultants face during the strategizing process?

RQ2: What are the interrelationships between the relevant liabilities?

$\mathrm{RQ3}$ : What are the associated mediating and moderating factors?

RQ4: To which extent do consultants experience the relevant liabilities?

Strategy-as-practice is regarded as the theory base of this study since it has been suggested that the "true power of strategy-as-practice lies in its ability to explain how strategy making is constrained" (Vaara and Wittington, 2012

First, a synopsis of the method and findings of the literature review is given. The methods and results of the semistructured interviews conducted in phase 2 of the research are then explained. This article concludes by presenting all the research findings in the form of a conceptual liabilities framework.

\section{Method}

\subsection{Phase 1: Integrative literature review}

\subsubsection{Research design}

Approached from a positivist-interpretivist paradigm and triggered by practical experience, the literature review was aimed at identifying consultant liabilities referred to in academic works. Literature was selected through a combination of an integrative literature review procedure (Nienaber, 2010) and the systems approach (Van As, 2002). This approach made it possible to discover the liabilities consultants face during the process of strategizing, the interrelationships between the relevant liabilities, and the mediating and moderating factors associated with the relevant liabilities.

\subsubsection{Results}

Seven management consultant liabilities, their associated preconditions, five mediating or moderating factors and the relationships between the liabilities were revealed. These results are summarised in Table 1.

Table 1: Consultant liabilities and their associated mediating and moderating factors in academic works

\begin{tabular}{|c|c|c|}
\hline \multicolumn{3}{|c|}{ Potential liabilities as identified in academic works } \\
\hline Liability & Definition & Authors \\
\hline $\begin{array}{l}\text { Problem } \\
\text { crystallisation }\end{array}$ & $\begin{array}{l}\text { The inability of the consultant to } \\
\text { recognise the root cause of the problem } \\
\text { combined with his/her inability to } \\
\text { articulate and communicate the } \\
\text { problem correctly. }\end{array}$ & $\begin{array}{l}\text { Antal and Krebsbach-Gnath, 2003; Cowen, 1986; Gable, 1996; Isaksem, } \\
\text { 2011; Knoeri et al., 2011; Lyles and Mitroff, 1980; Miller, 1994; } \\
\text { Mitroff and Featheringham, 1974; Neilson et al., 2008; Rumelt, 2011; Sun } \\
\text { Tzu, 2004; Turner, 1982; Werr and Linnarson (2002) }\end{array}$ \\
\hline $\begin{array}{l}\text { Successful } \\
\text { consulting }\end{array}$ & $\begin{array}{l}\text { The inability of the consultant to } \\
\text { convince the client the problem has } \\
\text { ultimately been addressed by members } \\
\text { of the organization, resulting in "internal } \\
\text { resistance" to the solution. }\end{array}$ & $\begin{array}{l}\text { Antal and Krebsbach-Gnath, 2003; Barry and Elmes, 1997; Gable, 1996; } \\
\text { Hendry, 2000; Jacobson et al., 2005; McLachlin, 2000; } \\
\text { Payne and Lumsden, 1987; Turner, 1982; Wright, } 2011\end{array}$ \\
\hline $\begin{array}{l}\text { Context } \\
\text { knowledge }\end{array}$ & $\begin{array}{l}\text { The inability of the consultant to } \\
\text { understand the organization's internal } \\
\text { and external environments, resulting in } \\
\text { misalignment between the consultant } \\
\text { and the specific organization's context. }\end{array}$ & $\begin{array}{l}\text { Anderson et al., 2006; Antal and Krebsbach-Gnath, 2003; Arend, 2004; } \\
\text { Bhawuk and Brislin, 2000; Ciampi, 2007; De Bruyn and Kruger, 2001; } \\
\text { Fincham, 1999; Fischlmayr, 2002; Greiner and Ennsfellner, 2010; } \\
\text { Harrington et al., 2009; Hendry, 2000; Hill, 2009; Hofstede, 2003; } \\
\text { Jeurissen and Van Luijk, 1998; Kieran, 1998; Kitay and Wright, 2007; } \\
\text { Lebestky and Tuggle, 1975; McKenna, 2001; Nielson et al., 2008; } \\
\text { Oosthuizen, 2008; Payne and Lumsden, 1987; Trommsdorff, 2011; } \\
\text { Turner, 1982; Yang and Haiwei, } 2006\end{array}$ \\
\hline
\end{tabular}




\begin{tabular}{|c|c|c|}
\hline $\begin{array}{l}\text { Influential } \\
\text { power }\end{array}$ & $\begin{array}{l}\text { The inability of the consultant to } \\
\text { influence management to commit to a } \\
\text { proposed strategy. }\end{array}$ & $\begin{array}{l}\text { Carter et al., 2008; Davenport and Early, 2010; Fullerton and West, 1996; } \\
\text { Göhler, 2009; Payne, 1987; Petersen and Poulfelt, 2002; Wright, } 2011\end{array}$ \\
\hline $\begin{array}{l}\text { Information } \\
\text { overload }\end{array}$ & $\begin{array}{l}\text { The inability of the consultant to } \\
\text { successfully navigate the vast amounts } \\
\text { of information available to and from } \\
\text { organizations. }\end{array}$ & $\begin{array}{l}\text { Davenport and Early, 2010; Edmunds and Morris, 2000; Göhler, 2009; } \\
\text { Harrington et al., 2009; Lubit, 2011; Neilson et al., 2008; Turner, } 1982\end{array}$ \\
\hline $\begin{array}{l}\text { Integrated } \\
\text { activity }\end{array}$ & $\begin{array}{l}\text { The inability of the consultant to fit the } \\
\text { recommended process changes to the } \\
\text { various activities already performed by } \\
\text { the client. }\end{array}$ & $\begin{array}{l}\text { Antal and Krebsbach-Gnath, 2003; Brüderl and Schüssler, 1990; } \\
\text { Campbell-Hunt, 2007; Davenport and Early, 2010; Hrebiniak, 2006; } \\
\text { Jarzabkowski, 2004; Kitay and Wright, 2007; Levinthal and Finchman, } \\
\text { 1988; Lumpkin and Dess, 2006; Lumsdaine and Lumsdaine, 1994; } \\
\text { Nielson et al., 2008; Pretorius and Holtzhauzen, 2008; Ward, 2004; } \\
\text { Wright, } 2011\end{array}$ \\
\hline Time & $\begin{array}{l}\text { The inability of the consultant to } \\
\text { manage time effectively (to comply with } \\
\text { the time requirements of a project). }\end{array}$ & $\begin{array}{l}\text { Appelbaum and Steed, 2005; Kitay and Wright, 2007; } \\
\text { Lebestky and Tuggle, 1975; Turner, 1982; Romano and Brna, } 2001\end{array}$ \\
\hline
\end{tabular}

\begin{tabular}{|c|c|c|}
\hline \multicolumn{3}{|c|}{ Potential mediating or moderating factors in academic works } \\
\hline Factor & Definition & Authors \\
\hline $\begin{array}{l}\text { Legitimacy } \\
\text { (mediator) }\end{array}$ & $\begin{array}{l}\text { The consultant is perceived to be legitimate when he/she is viewed } \\
\text { as successful, authentic, independent, reliable, appropriate, and } \\
\text { acting with integrity and honesty. }\end{array}$ & $\begin{array}{l}\text { Berglund and Werr, 2000; Singh et al., } \\
\text { 1986; Van Houten and Goldman, } \\
1981\end{array}$ \\
\hline $\begin{array}{l}\text { Consultant } \\
\text { adaptability } \\
\text { (mediator) }\end{array}$ & $\begin{array}{l}\text { The consultant's ability to adapt to and fit into an organization- } \\
\text { specific environment while playing the roles expected by the client. }\end{array}$ & $\begin{array}{l}\text { Kaarst-Brown, 1999; Kitay and Wright, } \\
2007\end{array}$ \\
\hline $\begin{array}{l}\text { Client engagement } \\
\text { (moderator) }\end{array}$ & $\begin{array}{l}\text { Client engagement pertains to the consultant's ability to gain the trust } \\
\text { of the client. }\end{array}$ & $\begin{array}{l}\text { Buday, 2003; Davenport and Early, } \\
\text { 2010; Fincham, 1999; Göhler, } 2009\end{array}$ \\
\hline $\begin{array}{l}\text { Cognitive recipe } \\
\text { (mediator) }\end{array}$ & $\begin{array}{l}\text { The consultant must be able to recognise his/her own cognitive } \\
\text { recipe's strengths and weaknesses and to use his/her strengths to } \\
\text { his/her own advantage and mitigate his/her weaknesses. }\end{array}$ & $\begin{array}{l}\text { Greiner and Ennsfellner, 2010; } \\
\text { Romano and Brna, 2001; Ward, } 2004\end{array}$ \\
\hline $\begin{array}{l}\text { Change } \\
\text { (moderator) }\end{array}$ & $\begin{array}{l}\text { Aiming for a once-off big solution rather than an incremental change } \\
\text { and ignoring the client's willingness to change. }\end{array}$ & Armenakis et al., 1993; Rumelt, 2011 \\
\hline
\end{tabular}

Source: Pretorius and Stander, 2012

Literature identifying factors that hinder management consultants in the process of strategizing is limited. It appears that for the last two decades, academia has focused on the relationship between consultants (in general) and their clients - as shown by Mcgivern (1983), Fullerton and West (1996) and Fincham (1999). The existing literature did, however, reveal that management consultants do indeed face several liabilities when assisting organizations in strategizing. Each of these liabilities is the combination of a unique set of "inability preconditions". It is the combined effect of these preconditions that acts as a potential barrier to the success of a management consultant. Several interrelationships between the "inability preconditions" have also been observed, suggesting that (excluding the liability of influential power where no obvious relationship has been observed) all the liabilities are related to various extents.

Phase 2 of the research was aimed at elaborating on phase 1 by using an qaulitative inquiry in the form of individual interviews. The interviews were conducted to confirm the literature as well as identify potential additional liabilities and establish the practical relevance of the liabilities identified in the literature review. The researchers reasoned inductively and observed patterns that emerged in the data without having a specific set of rules. The next section of this article is a synopsis of the methods and results of phase 2 .

\subsection{Phase 2: Methods}

\subsubsection{Sample; population and data credibility}

A non-probability, snowball sample was used (Noy, 2008). Ten consultants affiliated with well-known consulting firms, six independent consultants and one freelance consultant were interviewed. At this point, data saturation occurred and no further subjects were sought. 
The following measures were employed by reseachers to ensure that data gathered from the interviews is deemed credible (internal validity) (Creswell and Miller, 2010):

- evidence based recomendations obtained from interviews, are based on a non-probability sample of 17 subjects. According to Guest et al. (2006), one can make evidence-based recommendations on evidance gathered from 12 in-depth interviews as saturation is often reached before;

- prolonged engagement;

- two researchers from different philosophies; and

- peer debriefing.

Transferability (external validity) was sought through thick descriptions of both the research methods and findings. Dependability (reliability) and conformability were ensured by using ATLAS.ti, which automatically creates a clear audit trail, and the raw data was stored on a secure website.

As the interpretation of the data was made based on credible, tranferable and dependable data sources, they are deemed to be trustworthy an authentic (Schwandt et al, 2007)

\subsubsection{Data collection and analysis}

A semi-structured interview protocol questionnaire ${ }^{1}$ was used with each subject. All the subjects were asked identical questions in the same sequence, but the interviewers probed inductively for key responses.

During the interviews, the subjects were asked to rate the liabilities using the seven-point scale shown in Table 2.

Table 2: The seven-point liability rating scale used during individual interviews with consultants

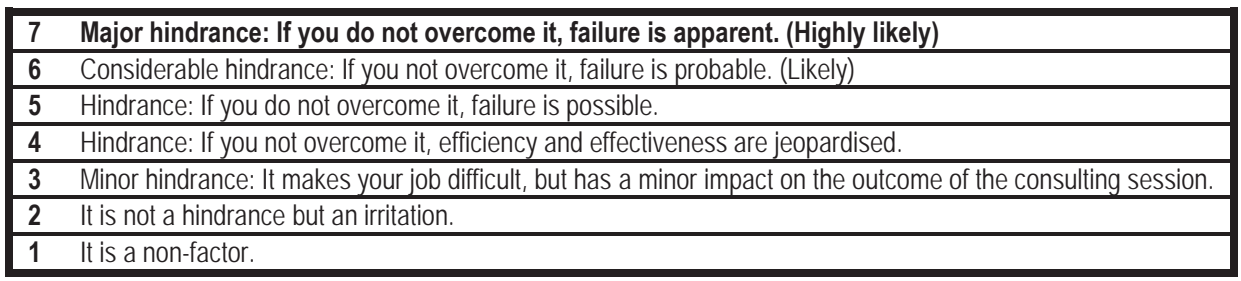

The data was collected between 11 October and 9 December 2011. The interviews were conducted in English and Afrikaans. The interviews were tape recorded and verbatim responses to each question were transcribed and translated using a standardised transcription protocol (McLellan et al., 2003).

The transcripts, field notes and tape recordings were then imported into ATLAS.ti (a qualitative research computer program) for analysis. The transcripts and tape recordings were linked using the association function of ATLAS.ti. By means of inductive reasoning, the data was first coded holistically and then initial deep coding was conducted. This resulted in 304 codes. These codes were then screened for similarities and patterns by means of descriptive coding, resulting in 50 code families. Pattern coding continued and 19 initial categories of liabilities emerged.. Consequently, autonomous counting was used (Hannah and Lautsch, 2011) to develop a summary of the data set. These numbers, together with the qualitative data gathered from Atlas.ti, were then scrutinised to discern the patterns reported in the next section of this article.

\section{Discussion}

\subsection{Empirical evidence from the interviews}

An analysis of the interview data resulted in the identification of 19 liabilities. Table 3 shows these liabilities and presents the associated quantitative data (obtained from the consultants' ratings of the various liabilities).

\footnotetext{
${ }^{1}$ The questionnaire is available from authors on request.
} 
Table 3: The liabilities identified during consultant interviews and associated quantitative data

\begin{tabular}{|lccccccc|}
\hline \multicolumn{1}{c}{ Liability } & $\mathbf{n}$ & Average & Median & Mode & SDev & High & Low \\
\hline Problem crystallisation & 12.00 & 6.29 & 7.00 & 7.00 & 1.08 & 7.00 & 4.00 \\
\hline Trust and relationships & 11.00 & 6.09 & 6.00 & 6.00 & 0.94 & 7.00 & 4.00 \\
\hline Integrated activity & 14.00 & 5.96 & 6.00 & 5.00 & 0.93 & 7.00 & 5.00 \\
\hline Unconsidered change & 3.00 & 5.67 & 6.00 & - & 1.53 & 7.00 & 4.00 \\
\hline Perception and expectation & 9.00 & 5.61 & 6.00 & 6.00 & 1.05 & 7.00 & 4.00 \\
\hline Communication competence & 9.00 & 5.44 & 5.50 & 4.00 & 1.16 & 7.00 & 4.00 \\
\hline Team functioning & 6.00 & 5.33 & 5.00 & 5.00 & 0.75 & 6.50 & 4.50 \\
\hline Context knowledge & 19.00 & 5.26 & 5.50 & 7.00 & 1.52 & 7.00 & 2.00 \\
\hline Individual prejudice & 4.00 & 5.25 & 5.50 & - & 1.71 & 7.00 & 3.00 \\
\hline Revenue attainment & 4.00 & 5.25 & 5.50 & - & 0.96 & 6.00 & 4.00 \\
\hline Influential power & 23.00 & 5.17 & 5.00 & 6.00 & 1.33 & 7.00 & 2.00 \\
\hline Time & 10.00 & 5.05 & 5.00 & 5.00 & 1.57 & 7.00 & 2.00 \\
\hline Scope creep & 3.00 & 5.00 & 5.00 & - & 0.00 & 5.00 & 5.00 \\
\hline Maverick consultants & 1.00 & 5.00 & 5.00 & - & & 5.00 & 5.00 \\
\hline Non-implementation & 3.00 & 5.00 & 5.00 & - & 1.26 & 6.00 & 3.50 \\
\hline Data and information & 21.00 & 4.43 & 4.00 & 4.00 & 1.34 & 7.00 & 2.00 \\
\hline Fast movers & 1.00 & 3.00 & 3.00 & - & & 3.00 & 3.00 \\
\hline Successful consulting & 11.00 & 2.36 & 1.00 & 1.00 & 2.38 & 7.00 & 1.00 \\
\hline Intellectual property & 1.00 & - & - & - & - & - & - \\
\hline
\end{tabular}

It is important to note that in Table $3, n$ refers to the number of times a specific liability and all its associated preconditions were mentioned by the subjects.

Table 4 is a matrix showing how the findings of the literature review were incorporated into the interview findings, with the number in the matrix indicating the average of the subjects' ratings for each liability.

Table 4: Liability matrix indicating how the findings of the literature review were confirmed by the interview findings and the averages of the subjects' ratings

Liabilities

Identified in literature

Moderating or mediating factors

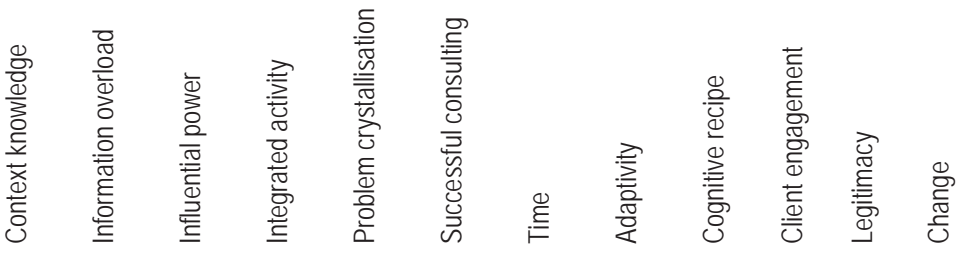

Communication competence

Context knowledge

n Data and information

Individual prejudice

Influential power

Integrated activity

$\subseteq$ Perception and expectation

Problem crystallisation

Revenue attainment

Scope creep

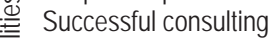

Team functioning

Time

Trust and relationships

Unconsidered change
$5.26^{*}$

$4.43^{*}$

$5.17^{*}$

5.96*

6.29 *

$5.61^{*}$
$2.36^{*}$

$5.05^{\star}$

$5.33^{*}$

$6.09 *$ 
The liability matrix in Table 4 indicates that the interviewed consultants confirmed the existence of most (all except the liability of successful consulting) of the liabilities identified in the literature. The liability of successful consulting, which was found to be an irritation, rather than a liability and the "migration path" of the mediating and moderating factors are discussed next.

\subsection{The liability of successful consulting}

The liability of successful consulting suggests that to ensure the implementation of a strategy, the organization must be convinced that the consultant is merely a mechanism for the organization to strategize (Barry and Elmes, 1997; Hendry, 2000; Wright, 2011). This liability on average scored as a level-two hindrance, with $47 \%$ of the subjects rating it as a nonfactor (level-one hindrance).However, the liability was scored as a level-four liability by senior consultants, suggesting that it could affect the efficiency and effectiveness of a consultant.

\subsection{Mediating or moderating factors}

The five mediating or moderating factors that were found to be integral parts of different liabilities were re-evaluated and re-classified, and then incorporated as follows:

- Legitimacy was incorporated into the liability of trust and relationships after it was emphasised by $24 \%$ of subjects.

- Adaptivity was integrated into the liability of perception and expectation after it was emphasised by $35 \%$ of subjects.

- Client engagement was emphasised by $29 \%$ of subjects and incorporated into the liability of trust and relationships.

- Cognitive recipe was emphasised by $29 \%$ of subjects and incorporated into the liability of team functioning.

- Change was integrated into the liability of unconsidered change as it was emphasised by $47 \%$ of subjects.

It is proposed that consultants need to mitigate 14 liabilities and four outlier liabilities in order to ensure the successful completion of a strategy-consulting project. The ratings of liabilities by the subjects are discussed next.

\subsection{The liability of communication competence}

In the opinion of $82 \%$ of subjects, consultants must have excellent communication skills - both verbal and non-verbal. Subjects rated communication competence as a level-five liability, which suggests that poor communication abilities could contribute to the failure of a consulting project.

\subsection{The liability of context knowledge}

The liability of context knowledge (or as Subject 15 described it "being relevant") was scored on average as a level-five hindrance by subjects, with the highest score seven and the lowest score 3.5 .

\subsection{The liability of data and information}

Overall, data overload was scored as a level-four hindrance, with the ability to jeopardise the efficiency and effectiveness of a consulting project.

\subsection{The liability of individual prejudice}

The subjects suggested that individuals with "an absolute intolerance of consultants" (Subject 12) who constantly question not only the work of the consultants but also their "ethics and professionalism" (Subject 13) can set a consultant up for failure. The subjects rated this liability as a level-five hindrance, thereby suggesting that it can make the failure of the consulting project possible. 


\subsection{The liability of influential power}

On average, the subjects scored the liability of influential power as a level-five hindrance, suggesting that failure to mitigate the liability could make failure of a consulting project possible. "You only talk to the decision makers who've got influence and power in the company when you sell that proposal to the company. You don't just walk into the projects. So you network in advance, and you'd find out who of the people are the decision makers ... otherwise you're wasting your time" (Subject 3).

\subsection{The liability of integrated activity}

Integrated activity, or systems thinking, is the "fundamentals of consulting, we need to be able to see the big picture as well as complete detail" (Subject 7). The subjects further suggested that "the more of a big picture approach you take, the more sustainable your solution is" (Subject 9). Subject 10 confirmed this statement and commented, "... I suppose anyone can, over time, figure out how the big picture and things fit in but you don't have time ..."

The subjects believed that if the liability of integrated activity (rated on average as a level-six hindrance) is not overcome, it would make the failure of the consulting project probable.

\subsection{The liability of perception and expectation}

On average, the subjects scored the inability to constantly manage the client's perceptions and expectations as a levelsix (6.5) hindrance - suggesting that if it is left unmanaged, the failure of the consulting project is apparent.

\subsection{The liability of problem crystallisation}

This liability specifically refers to consultants' ability to identify the correct cause of the problem encountered by the organization. Three (18\%) of the subjects suggested that due to the scoping agreement the consultant signed, consultants have to achieve the main deliverables set out in the agreement. They therefore rated the liability as a nonfactor.

However, $70 \%$ of subjects viewed root cause identification as a level six hindrance that, if not overcome, will make failure of the consulting project probable.

\subsection{The liability of revenue attainment}

Three preconditions are associated with the liability of revenue attainment:

- The price/time ratio: Subject 5 suggested that if the consulting fee is too small, the client often views the work of the consultant as being of substandard quality; if the consulting fee is too high, the client often thinks the consultant is too expensive.

- Non-payment: Subject 4 suggested that non-payment during the course of the project limits the consultant's ability to obtain the resources needed to complete the project successfully. Subject 3, however, was of the opinion that this is a hindrance specific to independent consultants and not large consulting firms.

- Cost control: Subject 15 and Subject 16 were of the opinion that the inability of consultants to consistently control the costs associated with a project is a hindrance to the success of a consulting project.

The liability of revenue attainment was given an overall rating of five, suggesting that failure to overcome this liability makes the failure of a consulting project possible.

\subsection{The liability of scope creep}

According to Subject 3, scope creep (the systematic increase, by the client, of the scope of a consulting project) results from unarticulated expectations and if it is left unmanaged, it will not only increase the time pressure on consultants but (Subject 8) will also make the failure of a project apparent through lack of revenue attainment. However, Subject 4 and Subject 5 were of the opinion that if the contract is correctly drawn up and the consultant gets additional time and fees for any additional work, scope creep is not a hindrance but an opportunity to sell-on. On average, scope creep was rated as a level-five hindrance. 


\subsection{The liability of team functioning}

Of the subjects, $64 \%$ considered consultants to be in the "solutions or problem-solving business" (Subject 4). The way people think defines their problem-solving method (cognitive recipe).

The subjects suggested that consultants who work for consulting firms can mitigate their weaknesses by working in a team. However, in order for a team to mitigate the weaknesses of the individual consultant's cognitive recipe, the team has to overcome the following preconditions:

- Team dynamic: The team dynamic (in terms of cognitive recipe, experience, context knowledge and specialist qualifications) must fit the deliverables stipulated in the contract (Subject 3).

- Over-utilisation: Specialist and/or senior consultants are often deployed to different projects simultaneously and have a "101 balls in the air" (Subject 3). More often than not, these consultants end up neglecting all the projects and leave junior consultants without a guide. This affects the consultant's ability to add value (Subject 3).

- Under-utilisation: Consulting firms often "sell too many consultants into a project" (Subject 7) and seasoned consultants are assigned to simple tasks, such as data capturing, which can be done more efficiently by junior staff. This hinders the ability of the consultants to provide organizations with value-adding solutions (Subject 7).

Team functioning on average scored as a level-five hindrance, with consultants suggesting that if a firm is not able to assign "the right team for the job" (Subject 3), the failure of the consulting project is possible.

\subsection{The liability of time}

Forty-nine per cent of the subjects consider time a level-five hindrance - suggesting that if it is not managed by the consultant, it could make the failure of a consulting project possible. However, the remaining $41 \%$ of the subjects were of the opinion that time in itself is "as much of a hindrance that you make it out" (Subject 12), mainly because the consultant is able to negotiate the time frame of the project in the contracting phase of the consulting process.

\subsection{The liability of trust and relationships}

"Consulting is about building relationships; if you don't have a relationship with the client, forget about consulting with the client. If I cannot trust you, I will never ever engage you as a consultant or I'll go to someone else" (Subject 3).

Of the subjects, $65 \%$ suggested that without trust and a relationship between the consultant and the client, buy-in is not possible. Trust and relationships scored, on average, as a level-six (6.5) hindrance - indicating that if a consultant cannot build a relationship that is based on trust with his or her client, the failure of the consulting project is apparent.

\subsection{The liability of unconsidered change}

Subject 2 was of the opinion that "the arrival of consultants implies that a degree of change is coming". It is this "implied change", together with "not understanding why the consultant is actually there" (Subject 7), that often cause resistance to consultants' suggestions. Forty-seven per cent of the subjects suggested that resistance to change is a liability to consultants. Rumelt (2011) regards unconsidered change as one of the four fatal flaws in strategizing with clients.

Subject 15 regarded unconsidered change part of the "legacy" of consultants and contended that "consultants like to be the 'glory boys', often entering the organization with a teacher/student mindset. They present workshops, mistake the nodding of heads for understanding, make changes and leave, often forgetting that in order to effect change they must win the hearts and minds of the organization."

"Unconsidered change increases the resistance of an organization to implement consultant [strategies]" (Subject 14). This was rated as a considerable hindrance (level 6) that could make the failure of a consulting project probable. Subject 9 suggested that the bigger the suggested change, the greater the resistance. Both Subject 7 and Subject 6 suggested that it is often better to introduce systematic change or continuous improvement rather than one big change.

The 14 liabilities identified above form the core of the liabilities framework. There are, however, four outlier liabilities that were also identified but were not repeated significantly.. These liabilities are also mentioned to give a complete picture of the data. 


\subsection{The liability of fast movers}

Subject 6 was of the opinion that consultants do not let "the dust settle" before they move on to the next project, suggesting that if a consultant does not let a solution "sink in" before he or she moves on, it might have an impact on the success of a project. Consequently, the subjects rated it as a level-three hindrance.

\subsection{The liability of intellectual property}

Subject 11 suggested that the question regarding whose intellectual property the solution is "is always a challenge".

\subsection{The liability of maverick consultants}

Subject 16 was of the opinion that consultants who take unnecessary risks become overly friendly with clients and "just want to get the job done regardless of the rules". The liability of maverick consultants was considered to be a level-five liability to any team that can make the failure of a consulting project possible.

\subsection{The liability of non-implementation}

The liability of non-implementation was mainly derived from the individual strengths and weaknesses listed by the subjects. However, two of the subjects suggested that consultants who do not drive the implementation of their own projects are setting their projects up for failure. They rated the liability of non-implementation as a level-five hindrance.

\section{Discussion of the Empirical Evidence}

The research was undertaken to answer four questions (RQs) as discussed below.

\subsection{RQ1: What are the liabilities consultants face during the strategizing process?}

The research results showed that although there is limited literature on the subject, under the specific term "liability", consultants do indeed experience several liabilities or hindrances in the strategizing process.

\subsection{RQ2: What are the interrelationships between the relevant liabilities?}

From the empirical evidence, it appears as if the various liabilities are indeed interrelated. The interrelationships between the liabilities that were identified from the empirical evidence are presented as a conceptual framework in Figure 1. The lines in Figure 1 that connect the various liabilities indicate the possible interrelationships between the various liabilities.

From Figure 1, it can be assumed that the following liabilities are of most importance since they appear to be interrelated to more than five of the other liabilities:

- problem crystallisation - interrelated with nine other liabilities

- context knowledge - interrelated with six other liabilities

- team dynamics - interrelated with six other liabilities

- time - interrelated with five other liabilities

- data and information - interrelated with five other liabilities 


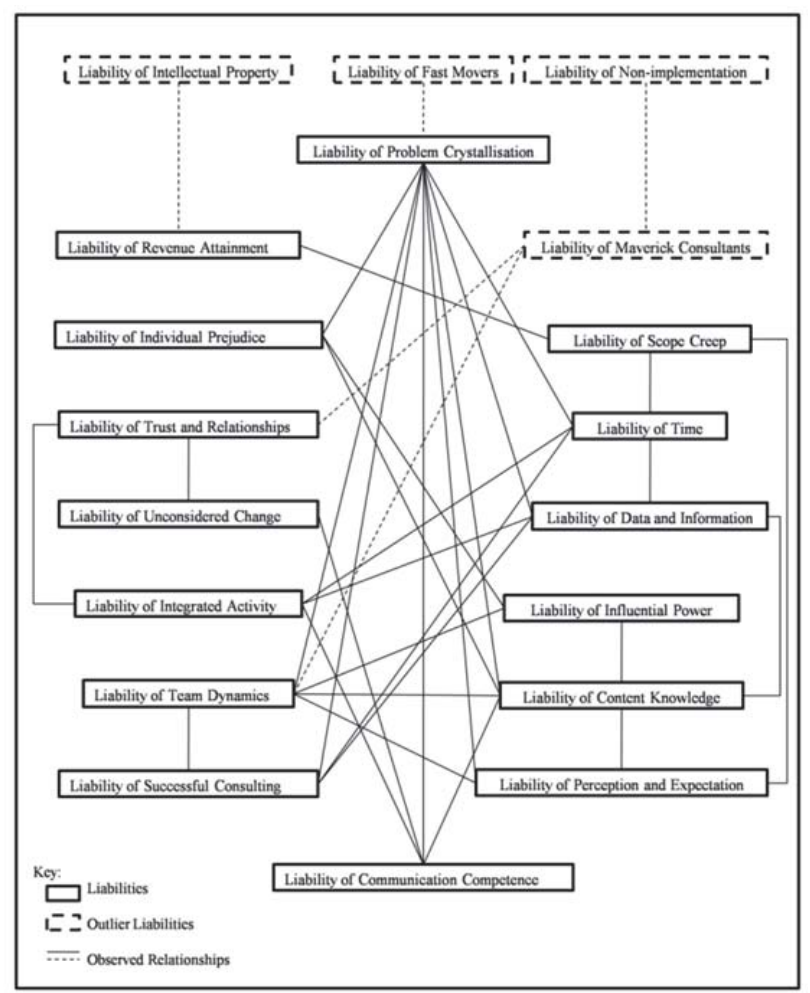

Figure 1 The observed liabilities management consultants face while assisting organizations in strategizing, including the observed relationship between the liabilities.

\subsection{RQ3:What are the associated mediating and moderating factors}

It is proposed that the following factors be considered to be either moderating or mediating variables. Observations without proof of mediating and moderating factors include the following:

- Consulting phase: It was observed that the liabilities are in general more likely to affect consultants in the early phases of the consulting process.

- Consultant affiliation: In general, the identified liabilities will have a stronger relationship with the success or failure (herein after "the relationship") of an independent consultant and small consulting firms.

- Consultant exposure: In general, the identified liabilities may have a weaker relationship with the success or failure of a national consultant. The strength of the relationship will increase as the consultant starts to consult in neighbouring countries and will most likely be the strongest when the consultant consults internationally.

- Experience level: Junior consultants with less than five years' experience are more likely to experience the liabilities than more experienced consultants.

- Engagement level: The higher a consultant's level of engagement with a client, the stronger the relationship between may become.

- Client demographics: The nature of the may be influenced by whether the client is a public-sector or privatesector organization; whether it is a small, medium or large organization; and the life cycle stage of the organization; and the industry in which the organization operates.

- Project type: The type of project (strategy formulation, strategy implementation or both) may influence the nature of the relationship.

- Consultant type: The nature of the relationship may be influenced by his or her area of specialisation and associated qualification level. 


\subsection{RQ4: To which extent do consultants experience the relevant liabilities?}

The empirical evidence suggests that consultants do indeed experience not only the liabilities identified in the literature but also the 18 (excluding the liability of successful consulting) potential management consulting liabilities.

\section{Conclusions}

The consultant sells value-adding solutions and change to the organization by getting the right information to the right person(s) at the right time and in the right format to enable the organization to make a decision.

Considering that the global market economy declined by 2.2\% in 2009 (World Bank, 2011) and that the management consulting industry experienced a $-9 \%$ growth rate (Von Uechtritz, 2010), it is possible that consultants are failing to provide their clients with value-adding solutions.

The research that informed this article was undertaken in an effort to explain an element of the "doing of strategy" by consultants (Jarzabkowski and Spee, 2009). In identifying the liabilities consultants experience in the process of assisting organizations in strategizing, the liability of successful consulting was found to be more of an irritation to consultants than a liability.

The 18 liabilities (six confirmed from the literature, eight identified in interviews and four outlier liabilities), the mediating or moderating factors that were identified and the observed interrelationships between the variables were combined into a conceptual liabilities framework. Figure 2 graphically depicts the conceptual liabilities framework resulting from the research.

Figure 2 Conceptual liabilities framework

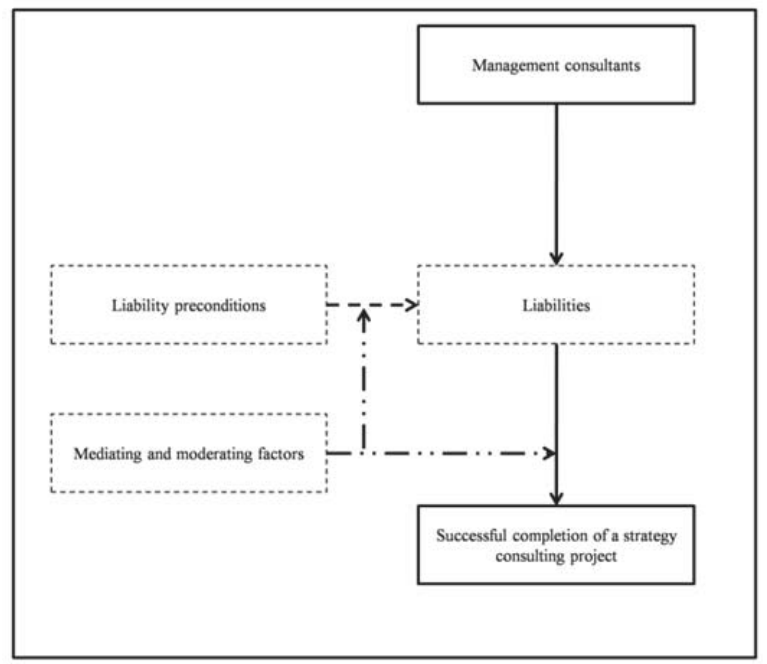

Figure 2 illustrates the liabilities that were found to intervene in the relationship between consultants' successful strategizing. Figure 2 further indicates that consultants will not be able to complete a strategy-consulting project successfully without mitigating some or all of these liabilities. The impact of these liabilities on the success of consultants is, however, influenced by mediating and moderating factors.

It is recommended that future research should investigate to which extent the liabilities influence the performance of consultants and their clients. A probability model, based on probability sampling methods that determine the extent to which mediating and moderating factors affect the impact of the liabilities should also be developed.

The conceptual liabilities framework presented in this article contributes to the accumulation of micro-strategy knowledge. Moreover, it should enable consultants to identify the liabilities they are likely to encounter during external strategy projects and can be used as a tool to make informed decisions. Used correctly, this framework should eventually reduce the number of consultants who are unable to strategize successfully. 


\section{References}

Anderson, J., Narus, J., \& Van Rossum, W. (2006). Customer value propositions in business markets. Harvard Business Review, 84(3), pp. 90-99.

Antal, A. B., \& Krebsbach-Gnath, C. (2003). Consultants as agents of organizational learning: The importance of marginality. In M. Dierkes, J. Child and I. Nonaka (eds), Handbook of Organizational Learning, pp. 462-484. Oxford: Oxford University Press.

Appelbaum, S. H., \& Steed, A. J. (2005). The critical success factors in the client-consulting relationship. Journal of Management Development, 24(1), pp. 68-93.

Arend, R. J. (2004). The definition of strategic liabilities, and their impact on firm performance. Journal of Management Studies, 41(6), pp. 10031027.

Armenakis, A. S., Harris, S. G., \& Mossholder, K. W. (1993). Creating readiness for organisational change. Human Relations, 46(6), pp. 681-703.

Barry, D., \& Elmes, M. (1997). Strategy retold: Toward a narrative view of strategic discourse. The Academy of Management Review, 22(2), pp. $429-452$.

Berglund, J., \& Werr, A. (2000). The invincible character of management consulting rhetoric: How one blends incommensurates while keeping them apart. Organization, 7(4), pp. 633-655.

Bhawuk, D. P., \& Brislin, R. W. (2000). Cross-cultural Training: A review. Applied Psychology: An International Review, 49(1), pp. $162-193$.

Brüderl, J., \& Schüssler, R. (1990). Organizational mortality: The liabilities of newness and adolescence. Administrative Science Quarterly, 35(3), pp. 530-547.

Buday, R. (2003). A consultants comeuppance. Harvard Business Review, 81(2), pp. 26-30.

Campbell-Hunt, C. (2007). Complexity in practice. Human Relations, 60(5), pp. 793-823.

Carter C., Clegg, S. R. \& Kornberger, M. (2008). So!apbox: Editorial essays: Strategy as practice? Strategic Organization. 6(1) pp 83-99.

Ciampi, F. (2007). Management consulting and knowledge creation, Symphonya: Emerging Issues in Management. Retrieved April 3, 2011, from http://webdepot.gsi.unimib.it/symphonya/RePec/pdf/symjournl46.pdf

Cowen, D. A. (1986). Developing a process model of problem recognition. The Academy of Management Review, 11(4), pp. 763-776.

Creswell, J. .W. \& Miller, D. L. (2010). Determining validity in qualitative inquiry. Theory Into Practice, 39(3), pp. 124-130.

Davenport, J., \& Early, J. (2010). The power-influence dynamics in a consultant/client relationship. Journal of Financial Service Professionals, 64(1), pp. 72-75.

De Bruyn, H. E., \& Kruger, S. (2001). Strategic Management: A South African Perspective. Johannesburg: Pearson Education.

Edmunds, A., \& Morris, A. (2000). The problem of information overload in business organisations: A review of the literature. International Journal of Information Management, 20(1), pp. 17-28.

Fincham, R. (1999). The consultant-client relationship: Critical perspectives on the management of organizational change. Journal of Management Studies, 36(3), pp. 335-351.

Fischlmayr, I.C. (2002). Female self-perception as barrier to international careers? International Journal of Human Resource Management, 13(5), pp. $773-783$.

Fullerton, J., \& West, M. A. (1996). Consultant and client - Working together? Journal of Managerial Psychology, 6, pp. 40-49.

Gable, G. G. (1996). A Multidimensional model of client success when engaging external consultants. Management Science. 42(8): 1175-1198.

Göhler, G. (2009). Power to and power over. In S.R. Clegg and M. Haugaard (eds), The Sage Handbook of Power, pp. 27-39. London: Sage.

Guest, G., Bunce, A., \& Johnson, L. (2006). How many interviews are enough?: An experiment with data saturation and variability. Field Methods, 18 , pp. $59-82$

Greiner, L., \& Ennsfellner, I. (2010). Management consultants as professionals, or are they? Organizational Dynamics, 39(1), pp. $72-83$.

Hannah, D. R., \& Lautsch, B. A. (2011). Counting in Qualitative Research: Why to Conduct it, When to Avoid it, and When to Closet it. Journal of Management Inquiry's, 20(1) pp. 59-82.

Harrington, H. J., Gupta, P., \& Voehl, F. (2009). The Six Sigma Green Belt Handbook. Chicago: Paton Professional.

Hendry, J. (2000). Strategic decision making, discourse, and strategy as social practice. Journal of Management Studies, 37(7), pp. 955-978.

Hill, C. W. (2009). International Business. $7^{\text {th }}$ Edition. New York: McGraw-Hill//rwin.

Hofstede, G. (2003). What is culture? A reply to Baskerville. Accounting Organization and Society, 28, pp. 811-813.

Hrebiniak, L. G. (2006). Obstacles to effective strategy implementation. Organizational Dynamics, 35(1), pp. 12-31.

Isaksem, S. G. (2011). Creative Approaches to Problem Solving: A Framework for Innovation and Change. 3rd Edition. Thousand Oaks, CA: Sage.

Jacobson, N., Butterill, D., \& Goering, P. (2005). Consulting as a strategy for knowledge transfer. Milbank Quarterly, 83(2), pp. $299-321$.

Jarzabkowski, P. (2004). Strategy as practice: Recursiveness, adaptation, and practices-in-use. Organizational Studies, 25(4), pp. 529-560.

Jarzabkowski, P., \& Spee, A. P. (2009). Strategy-as-practise: A review and future directions for the field. Journal of Management Reviews, 11(1), pp. 69-95.

Jeurissen, R. J., \& van Luijk, H. J. (1998). The ethical reputations of managers in nine EU-countries: A cross-referential survey. Journal of Business Ethics, 17, pp. 995-1005.

Kaarst-Brown, M. L. (1999). Five symbolic roles of the external consultant - Integrating change, power and symbolism. Journal of Organizational Change Management, (12)6, pp. 540-561.

Kelloggforum. (2010). Higher education web-blog: Top 10 consulting firms. Retrieved April 3, 2011, from http://www.kelloggforum.org/top-10consulting-firms/

Kieran, E. (1998). The development of understanding. In D.R. Olson and N. Torrance (eds), The Handbook of Education and Human Development, chapter 23 Blackwell. DOI: 10.1111/b.9780631211860.1998.00025.x (accessed 11 July 2011).

Kitay, J., \& Wright, C. (2007). From prophets to profits: The occupational rhetoric of management consultants. Human Relations, 60(11), pp. $1613-1640$

Knoeri, C., Binder C. R., \& Althause, H. (2011). An agent operationalization approach for context-specific agent-based modelling. Journal of Artificial Societies and Social Simulations, 14(2), pp. 4-22. 
Lebestky, D. A., \& Tuggle, F. D. (1975). Manager-consultant conflict: An experiential approach. The Academy of Management Journal, 18(2), pp. 375-381.

Levinthal, D. A., \& Finchman, M. (1988). Dynamics of interorganizational attachments: Auditor-client relationships. Administrative Science Quarterly, 33, pp. 345-348.

Lubit, R. (2011). Tacit knowledge and knowledge management: The keys to sustainable competitive advantage. Organizational Dynamics, 29(3), pp. 164-178.

Lumpkin, G. T., \& Dess, G. G. (2006). The effect of simplicity on the strategy performance relationship: A note. Journal of Management Studies, 43(7), pp. 1583-1604.

Lumsdaine, E., \& Lumsdaine, M. (1994). Creative Problem Solving: Thinking Skills for a Changing World. New York: McGraw-Hill.

Lyles, M. A., \& Mitroff, I. I. (1980). Organizational problem formulation: An empirical study. Administrative Science Quarterly, 25, pp. 109-119.

Mcgivern, C. (1983). Some facets of the relationship between consultants and clients in organizations. Journal of Management Studies, 20, pp. 367-386.

McKenna, C. D. (2001). The world's newest profession: Management consulting in the twentieth century. Enterprise and Society, 2(4), pp. 673679.

McLachlin, R. (2000). Service quality in consulting: What is engagement success? Managing Service Quality, 10(3), pp. $141-150$.

McLellan, E., MacQueen, K. M. \& Neidig, J. L. (2003). Beyond the Qualitative Interview: Data Preparation and Transcription. Field Methods (15)1, pp: 63-84

Miller, J. R. (1994). How to work with consultants. Training and Development Journal, 48(12), pp. 15.

Mitroff, I. I., \& Featheringham, T. R. (1974). On systemic problem solving and the error of the third kind. Behavioural Science, 19(6), pp: 383-393.

Neilson, G. L., Martin K. L. \& Powers E. (2008). The secrets to successful strategy execution. Harvard Business Review, 86(6), pp. 60-70.

Nienaber, H. (2010). Conceptualisation of management and leadership. Management Decision, 48(5), pp. 661-675.

Noy, C. (2008). Sampling knowledge: The hermeneutics of snowball sampling in qualitative research. International Journal of Social Research Methodology, 11(4), pp. 327-344.

Ooghe, H., \& de Prijcker, S. (2008). Failure processes and causes of company bankruptcy: A typology. Management Decision, 46(2), pp. 223242

Oosthuizen, T. (ed) (2008). Management. $3^{\text {rd }}$ Edition. South Africa, Oxford University Press.

Payne, A. (1987). A European view of management consulting, European Management Journal, 5(3), pp. 154-162.

Payne, A., \& Lumsden, C. (1987). Strategy consulting - A shooting star? Long Range Planning, 20(3), pp. 53-64.

Petersen, N. J., \& Poulfelt, F. (2002). Knowledge management in action: A study of knowledge management in management consultancies. In A.F. Buono (ed.), Developing Knowledge and Value in Management Consulting, pp. 33-60. Greenwich, Conn.: Information Age Publishing.

Pretorius, M., \& Holtzhauzen, G. T. (2008). Critical variables of venture turnarounds: A liabilities approach. Southern African Business Review, 12(2), pp. 408-430

Pretorius, M., \& Stander, K. (2012). AJBM. Retrieved from http://academicjournals.org/journal/AJBM/article-abstract/605CA9129104

Romano, D. M., \& Brna, P. (2001). Presence and reflection in training: Support for learning to improve quality decision making skills under time limitations. Cyber Psychology and Behaviour, 4, pp. 265-277.

Rumelt, R. (2011). The perils of bad strategy, McKinsey Quarterly. Retrieved July 8, 2011, from https://www.mckinseyquarterly.com /Strategy/Strategic_Thinking/The_perils_of_bad_strategy_2826

Singh, J. V., Tucker, D. J., \& House, R. J. (1986). Organizational legitimacy and the liability of newness. Administrative Science Quarterly, 31(2), pp. 171-193.

Schwandt, T. A., Lincoln, Y. S. and Guba, E. G. (2007), Judging interpretations: But is it rigorous? trustworthiness and authenticity in naturalistic evaluation. New Directions for Evaluation, pp. 11-25.

Sun Tzu. (2004). The art of war. Trans. by T. Clearly. Boston: Shambhala Publications.

Trommsdorff, G. (2011). Development of "agentic" regulation in cultural context: The role of self and world views. Child Development Perspectives, 6, pp. 19-26.

Turner, A. N. (1982). Consulting is more than giving advice. Harvard Business Review, 60(5), pp. 120-129.

Vaara, E., \& Whittington, R. (2012). Strategy-as-practise: Taking social practises seriously. The Academy of Management Annuals. Retrived from http://dx.doi.org/10.1080/19416520.2012.672039

Van As, S. C. (2002). Guidelines for Reports, Dissertations and Theses. Departmental Guidelines. Pretoria: University of Pretoria.

Van Houten, D. R., \& Goldman, P. (1981). Contract consulting's hidden agenda: A quest for legitimacy in government. The Pacific Sociological Review, 24(4), pp. 461-493.

Vault (2011). Consulting firm rankings. Retrieved April 3, 2011, from http://www.vault.com/wps/portal/usa/rankings/individual?rankingld1 $=0 \&$ rankingld2=1\&rankings $=1 \&$ regionld $=0$

Von Uechtritz, M. (2010). Market share analysis: Top 10 consulting providers revenue, growth and market share, worldwide and regional, 2009. Retrieved 13 March, 2012, from http://www.deloitte.com/assests/DcomGlobal/Locl\%20Assests/Documents/Press/deloitte_vol2_article3.pdf

Ward, T. (2004). Cognition, creativity, and entrepreneurship. Journal of Business Venturing, 19, pp. 173-188.

Werr, A., \& Linnarson, H. (2002). Management consultant for client learning? Clients perception of leaning in management consultancy. In A.F. Buono (ed), Developing Knowledge and Value in Management Consulting, pp. 3-32. Greenwich, Conn.: Information Age Publishing.

World Bank, (2011). Economy. Retrieved 13 March, 2012, from http://data.worldbank.org/sites/defaultffiles/section4.pdf

Wright, A.D. (2011). Author, authoring, de-authoring and authorization: Consultants texts and translation. Paper presented at the EGOS 2011 Conference, Sweden.

Yang, Z., \& Haiwei, Z. (2006). Strategy cognition of Chinese enterprise managers: Learning, reconstruction and integration innovation of east and west strategy thoughts. IFSAM 8th Wold Congress, Germany. 